\title{
PGPR Improves the Tolerance on Vitis vinifera cv. Alphonse Lavalle Grown Under Lead Stress
}

\section{Emine Sema Çetin* and Selda Daler}

Department of Horticulture, Faculty of Agriculture, Yozgat Bozok University, Yozgat, Turkey

*Corresponding Author: Emine Sema Çetin, Department of Horticulture, Faculty of Agriculture, Yozgat Bozok University, Yozgat, Turkey.
Received: March 02, 2020

Published: March 31, 2020

(C) All rights are reserved by Khan Salman., et al.

\section{Abstract}

Heavy metals are one of the major ecological problems for all living beings, accumulating more and more in surroundings such as soil, water and air. It also causes severe harm to plants, primarily causing deteriorations in growth and development, and in advanced cases, the death of the plant. One of these heavy metals is lead. It is an element that reaches soils mostly through the automobile industry and through the use of leaded pesticides and it is not essential to plants, but rather negatively affects growth and development. The purification of soils contaminated by heavy metals is not possible especially in the short term. Because of these reasons, it is extremely difficult to remove the heavy metal contamination in the soil. Some rhizobacteria living freely in the soil affect plant development due to their functions such as making phytohormone and vitamin synthesis, inhibiting ethylene synthesis, enhancing stress resistance, facilitating nutrient intake and phosphate resolving. Some rhizobacteria were detected to be able to reduce heavy metals to less toxic forms. With this research, it was aimed to determine the effects of PGPR applications on lead $\left(\mathrm{Pb}\left(\mathrm{NO}_{3}\right)_{2}\right)$ stress in Alphonse Lavallee grapevine variety grafted on 1103 Paulsen grapevine rootstock. For this purpose, lead (10 and 25 ppm Pb( $\left.\mathrm{NO}_{3}\right)_{2}$ ) was added to both environments with PGPR inoculated and uninoculated plants, some physical (shoot length, shoot weight and average number of leaves per shoot) and biochemical analyses (chlorophyll content, degree of membrane damage, proline, total phenolic content, lipid peroxidation and mineral content) were made. As a result of the research, PGPR applications were found to be extremely effective in preventing heavy metal stress caused by lead or in mitigating the stress severity.

Keywords: Grapevine; PGPR; Heavy Metal; Chlorophyll; Phenolic Content; Mineral Matter

\section{Introduction}

Heavy metals are generally defined in different ways depending on their density, atomic weight, chemical properties or toxicity, and are often expressed as metals whose density is greater than $5 \mathrm{~g} / \mathrm{cm}^{3}$ [1]. Heavy metals are an environmental problem that threatens the lives of all living beings by accumulating more and more in surroundings such as soil, water and air. Their accumulation in soil impairs soil fertility and ecosystem, besides, they can be transported from one organism to another through the food chain and sustain their damages for years [2].

Heavy metals such as manganese, iron, copper and zinc are essential elements for plants [3]. For example, copper and zinc are essential cofactors for the structure of proteins and enzymes that play an important role in the growth and development of plants [4]. However, the accumulation of some heavy metals such as lead, mercury and cadmium causes damage to the plant. Lead is a heavy metal that reaches soils from the automobile industry and from the use of leaded pesticides. It is an element that affects the plant water regime due to its negative effect on cell turgor and cell wall stability in plants, reducing stoma movements and leaf area. It also reduces the intake of cation and anions of plants because of re- ducing root development, thus affecting nutrient intake [5]. Heavy metal accumulation negatively impacts many events such as photosynthesis [6], transpiration [7], membrane integrity [8], enzyme activity [9] and germination [10]. Especially in the short term, it is not possible to purify the soil contaminated with heavy metals of these elements. That is why heavy metals are the elements that cannot be destroyed biologically, however, they can be transformed from one organic complex to another by oxidation. For these reasons, it is extremely difficult to diminish the heavy metal pollution in the soil. Engineering methods are often used to improve such lands, which is often expensive and requires a lot of effort. Therefore, considering that it is extremely difficult to free soils from heavy metals and that it is also a necessity to produce plants, applications that will increase the resistance of plants against these elements, on the other hand, reduce the effectiveness of pollutants in soils have great importance.

The conducted research shows that some rhizobacteria called PGPR are effective in metal binding and metal purification in metal biosorption studies [11]. Bacteria belonging to the genera Arthrobacter, Citrobacter, Enterobacter and Pseudomonas are known to be effective in this regard. Some research has been done to determine 
the effects of these PGPR bacteria on reducing heavy metal stress in plants [12-14] and it was determined that PGPR application was effective in these research results.

\section{Aim of the Study}

This study aims to examine the detrimental effects of lead on the grapevine and the effects of PGPRs on the prevention/mitigation of these damages in case the lead element, which is a widespread element in the environment due to its extensive use in industrial and agricultural activities, is more in cultivation soil.

\section{Material and Method \\ Material}

In the research, Alphonse Lavallee grape variety grafted on the grapevine rootstock of 1103 Paulsen (1103 P) was used as plant material. $1103 \mathrm{P}$ is an American grapevine rootstock that develops strongly, has high rooting and grafting rate, can adapt well to moist and clayey-calcareous soils, and can withstand $17-18 \%$ active lime and $0.6 \mathrm{~g} \mathrm{NaCl} / \mathrm{kg}$ of salt. Alphonse Lavallee is widely cultivated, seeded, suitable for storage and transportation, and have large clusters and grapes with purplish-black color. Plant materials were obtained from a commercial company (Bursa Tarım/ TURKEY) as grafted. The sterile mixture of garden soil:pearlite:turf was used in equal proportion as the growing medium. Grafted cuttings planted in polyethylene bags with $2 \mathrm{~L}$ volume were placed in cultivation rooms at $24 \pm 1^{\circ} \mathrm{C}$ temperature and under controlled conditions. PGPR inoculation of $5 \mathrm{~mL}$ was made to the root area of grafted cuttings about $15^{\text {th }}$ days after planting. The PGPRs used in the research were obtained from a commercial company (ROA Biyoteknoloji/Antalya/TURKEY) as a ready-made solution consisting of Arthrobacter bacteria. Approximately three weeks after PGPR application, lead $\left(\mathrm{Pb}\left(\mathrm{No}_{3}\right)_{2}\right)$ solution was applied to the root area of grafted cuttings in pots at the doses of 10 and $25 \mathrm{ppm}$. In these conditions, cuttings were kept in cultivation environment for a period of approximately 2 months. After root and shoot development, grafted saplings were rooted out, and physical and biochemical examinations were carried out.

\section{Method}

In this study investigating the physical and biochemical effects of PGPR application on grapevine saplings exposed to lead stress, the physical and biochemical analyses were carried out, which is given below in detail.

Physical analysis: Shoot length (cm), shoot weight (g) and the average number of leaves per shoot (pieces) were examined.

Biochemical analyses

Chlorophyll content: Chlorophyll content was calculated by SPAD method using Konica Minolta SPAD-502 Plus device.
Degree of membrane damage: Membrane damage was determined as a percentage (\%) through the measurement of excess electrolytes given out by plant cells under stress conditions [15].

Proline content: Proline content of the samples was determined according to the method of Bates., et al [16]. Spectrophotometer readings were made at $520 \mathrm{~nm}$, proline quantities were demonstrated as $\mu \mathrm{M} / \mathrm{g}$ fresh weight.

Total phenolic content: To determine the total phenolic content, the leaf samples were thoroughly crushed using liquid nitrogen in a mortar, then extracted according to the method of Kiselev., et al [17]. Total phenolic content analyses were performed according to Singleton and Rossi [18] using the Folin Ciocalteu colorimetric method. Spectrophotometer readings were made at $765 \mathrm{~nm}$ wavelength and the total amounts of phenolic content were given in $\mathrm{mg} / \mathrm{g}$ in the form of gallic acid equivalent (GAE).

Lipid peroxidation: Lipid peroxidation was determined according to Zhang., et al. [19] on the principle of measuring the amount of malondialdehyde, the final product of oxidation, and the results are given in $\mu \mathrm{M} / \mathrm{g}$ (Fresh weight).

Mineral compounds: It was detected using ICPMS (Inductively Coupled Plasma Mass Spectrometry) at Yozgat Bozok University Scientific and Technology Application and Research Center.

\section{Statistical analysis}

The research was organized to include 2 different PGPR applications (both inoculated and uninoculated with PGPR) and 3 different lead applications (0,10 and 25 ppm). SPSS 24.0 package software was used to interpret the results obtained in the research which was planned to have 3 replications and 10 plants in each replication according to the random blocks trial design. Differences between the applications were determined by Duncan multiple comparison test.

\section{Results and Discussion}

The results of this research showing the effects of PGPR applications on lead stress are presented below. Although there are no statistically significant differences in the study, it was determined that the longest shoots were found in the plants of the environments inoculated with PGPR.

The heaviest shoots were also obtained from the environments inoculated with PGPR (Table 1). It is also observed that the average number of leaves per shoot is less in plants that are not inoculated with PGPR and in the lead-containing environments.

In the studies aimed at determining the damage caused by lead stress in plants, it was determined that many physical characteristics were negatively affected. Zengin and Munzuroglu [20] stated 


\begin{tabular}{|c|c|c|c|c|}
\hline \multirow{2}{*}{ PGPR } & $\mathbf{( P b}\left(\mathbf{N O}_{3} \mathbf{~}_{\mathbf{2}} \mathbf{)} \mathbf{( p p m )}\right.$ & Shoot length (cm) & Shoot weight (g) & Average leaf number per shoot (piece) \\
\hline \multirow{3}{*}{ Inoculated } & 0 & $30,69 \mathrm{ab}$ & $4,79 \mathrm{a}$ & $6,19 \mathrm{a}$ \\
\cline { 2 - 5 } & 10 & $24,94 \mathrm{ab}$ & $3,89 \mathrm{abc}$ & $6,13 \mathrm{ab}$ \\
\cline { 2 - 5 } & 25 & $35,72 \mathrm{a}$ & $4,67 \mathrm{ab}$ & $6,11 \mathrm{ab}$ \\
\hline \multirow{3}{*}{ Uninoculated } & 0 & $22,15 \mathrm{~b}$ & $2,48 \mathrm{~d}$ & $4,52 \mathrm{abc}$ \\
\cline { 2 - 5 } & 10 & $25,33 \mathrm{ab}$ & $2,51 \mathrm{c}$ & $3,43 \mathrm{c}$ \\
\cline { 2 - 5 } & 25 & $29,24 \mathrm{ab}$ & $3,23 \mathrm{bc}$ & $4,22 \mathrm{bc}$ \\
\hline
\end{tabular}

Table 1: Effects of PGPR applications on physical properties in heavy metal stress.

*: There is a statistical difference between the averages indicated by different letters in the same column $(\mathrm{P} \leq 0.05)$.

that lead negatively affects root, stem and leaf development in plants.

Kıran., et al. [9] also found that lead stress causes a decrease in biomass, stem and root length and leaf area values in cabbage lettuce. In the research on PGPR application, Yolcu., et al. [21] examined the effect of PGPRs on the yield and quality criteria of Hungarian vetch (Vicia Pannonica Crantz) and found that it had positive effects on values such as plant height and the number of leaves.
Hassan., et al. [22] applied 6 different PGPR genus to the corn (Zea mays L.) with lead stress and determined that the length of the shoot increased. Ogar., et al. [23] determined that biological agents such as PGPR significantly increased shoot and root dry weight in scarlet pimpernel and alfalfa plants under zinc and lead stress.

In the scope of the study, the effects of PGPR on some biochemical properties were also investigated and the results were presented in table 2.

\begin{tabular}{|c|c|c|c|c|c|c|}
\hline \multirow{2}{*}{ PGPR } & $\begin{array}{c}\left(\mathbf{P b}\left(\mathbf{N O}_{\mathbf{3}} \mathbf{~}_{\mathbf{2}} \mathbf{)}\right.\right. \\
(\mathbf{p p m})\end{array}$ & $\begin{array}{c}\text { Chlorophyll } \\
(\mathbf{S P A D})\end{array}$ & $\begin{array}{c}\text { Degree of membrane } \\
\text { injury (\%) }\end{array}$ & $\begin{array}{c}\text { Proline } \\
(\boldsymbol{\mu} \mathbf{M} / \mathbf{g})\end{array}$ & $\begin{array}{c}\text { Total phenolic } \\
\mathbf{c o m p o u n d}(\mathbf{m g} / \mathbf{g})\end{array}$ & $\begin{array}{c}\text { Lipid peroxidation } \\
(\boldsymbol{\mu} \mathbf{M} / \mathbf{g})\end{array}$ \\
\hline \multirow{3}{*}{ Inoculated } & 0 & $27,21 \mathrm{a}$ & $21,25 \mathrm{e}$ & $4,57 \mathrm{e}$ & $1,38 \mathrm{c}$ & $42,58 \mathrm{e}$ \\
\cline { 2 - 7 } & 10 & $26,90 \mathrm{ab}$ & $54,44 \mathrm{~d}$ & $5,18 \mathrm{de}$ & $1,31 \mathrm{c}$ & $50,75 \mathrm{~d}$ \\
\cline { 2 - 7 } & 25 & $21,94 \mathrm{bc}$ & $63,92 \mathrm{c}$ & $10,84 \mathrm{a}$ & $2,64 \mathrm{a}$ & $70,90 \mathrm{~b}$ \\
\hline \multirow{3}{*}{ Uninoculated } & 0 & $25,49 \mathrm{ab}$ & $23,42 \mathrm{e}$ & $5,47 \mathrm{~cd}$ & $1,44 \mathrm{c}$ & $53,80 \mathrm{~d}$ \\
\cline { 2 - 7 } & 10 & $19,88 \mathrm{c}$ & $73,71 \mathrm{~b}$ & $7,23 \mathrm{~b}$ & $1,67 \mathrm{~b}$ & $62,48 \mathrm{c}$ \\
\cline { 2 - 7 } & 25 & $17,80 \mathrm{c}$ & $82,22 \mathrm{a}$ & $6,31 \mathrm{c}$ & $2,22 \mathrm{~b}$ & $82,47 \mathrm{a}$ \\
\hline
\end{tabular}

Table 2: Effects of PGPR on biochemical properties in heavy metal stress

*: There is a statistical difference between the averages indicated by different letters in the same column $(\mathrm{P} \leq 0.05)$.

Photosynthesis is the process of producing organic compounds using light energy in chlorophyll-bearing organisms, and the main structure in this event, which is vital for living beings, is chlorophyll. The amount of chlorophyll in the leaves varies due to many environmental factors [24].

Heavy metals are one of these factors, causing the pigments to deteriorate. A study on flix weed (Descurainia sophia) reported reduced chlorophyll content in plants in case of the presence of heavy metals [25]. In this study, it was found that the presence of heavy metal had a negative effect on the pigments, although the pigments in the plants containing 10 ppm lead and in the PGPRadministered plants were less damaged. In parallel with our research, Janmohammadi., et al. [8] and Hassan., et al. [22] also stated that the chlorophyll content in lead stress increased with PGPR treatments. Wang., et al. [26] also noted that the amount of chlorophyll and carotenoids decreased in heavy metal stress, although increased by inoculation of PGPR and mycorrhiza.
The protection of membrane integrity in plants under stress is a serious indicator for the protection of the plants from stress. The higher the membrane damage, the more severe the stress of the plant. Heavy metals are also known to cause membrane damage [8]. In our research, the highest membrane damage was found in plants in which PGPR was not inoculated and plants in the environment with high doses of lead. The least damage was determined in plants in the environment without lead.

Plants have developed different mechanisms to protect their cells under stress conditions that are not suitable for them. Proline accumulation is one of these mechanisms and is effective as an osmotic preservative $[27,28]$. Our research also examined the treatment of lead causing to stress in plants and it is seen that the osmotic regulation in question also occurs there. It is observed that osmotic regulation is more effective in plants that are inoculated with PGPR in the presence of $25 \mathrm{ppm}$ lead, that is, the amount of 
proline significantly increased $(10.84 \mu \mathrm{M} / \mathrm{g})$, therefore, the mechanism of protection of the plant is also working effectively, although a severe stress is observed in the environment. Vardharajula., et al. [29] investigated the effectiveness of PGPRs against drought stress in maize and stated that the plants' proline content increased in these applications. Janmohammadi., et al. [8] recorded that PGPR administration in lead stress in wheat caused an increase in proline quantity. Hassan., et al. [22] researched the effectiveness of 6 different PGPR genus in corn grown under lead stress and found that PGPR applications increased the proline content.

One of the most important secondary metabolites synthesized in plants under different environmental factors is phenolic compounds, with high antioxidant functions. It is known that there is an increase in the metabolism of phenylpropanoid and the amount of phenolic compounds under stress in plants [30-32]. It has been detected that PGPRs promote the synthesis of these compounds for preventing stress in plants. As a matter of fact, our study revealed that the total amount of phenolic content $(2.64 \mathrm{mg} / \mathrm{g})$ was the highest in the plants where $25 \mathrm{ppm}$ lead was applied and PGPR was inoculated. Similar results were found in a study examining the effects of PGPRs on pathogenic stress in pea, and the total phenolic content in inoculated plants increased [33]. Pazoki [34] who investigated the effects of PGPR and mycorrhizas in wheat plant grown in different lead concentrations, noted that PGPR treatments against lead stress increased the phenolic content by approximately 17.9\%. Pešaković., et al. [35] also noted that PGPR treatments in strawberries provided increases in phenolic content and antioxidant capacity.

Another detriment of heavy metals is that hydrogen is extracted from unsaturated fatty acids via reactive oxygen species, causing peroxidation in lipids [36,37]. The most basic criteria for detecting lipid peroxidation is the determination of the malondialdehyde (MDA) content, the final product of the oxidation. The conducted research has shown that the stress of lead in cabbage lettuce [9] and in rice [38] raises the amount of MDA. In our research, it is observed that stress is the highest in the environments containing $25 \mathrm{ppm}$ lead due to oxidation $(82.47 \mu \mathrm{M} / \mathrm{g})$. However, in plants which PGPR was administered to, by giving the lead in the same dose, oxidation was found to be at lower levels. Similarly, Wang., et al. [26] stated that PGPR treatments in arsenic-rich soils reduce lipid peroxidation in plants. Haneef., et al. [39] recorded that the amount of MDA in Psyllium (Plantago ovata) which was exposed to cadmium stress was high, while PGPR and mycorrhiza applications reduced this value.

Another one of the investigations in our study to determine whether PGPR applications effectively prevent lead stress is the measurement of mineral compounds in the leaves of plants. The most important criteria for determining plant nutrition is the determination of leaf mineral content. At the same time, leaf mineral content is an indicator in the preparation of fertilization programs for determining and overcoming deficiencies. It is known that the contents of leaf mineral matter decrease in all kinds of environments that prevent the development of plants. This study examined the amount of mineral matter in the leaves of plants under the lead stress (Table 3).

In our research, in the plant leaves that were not inoculated with PGPR and that are under 25 ppm lead stress, the amounts of all elements except lead appear to be low. It is understood in general that especially in macro elements, the positive effects of PGPR applications are clearer (Table 3). Similar to the results we obtained from the study, Sabır., et al. [40] investigated the effects of PGPR strains on the vegetative development and mineral intake of $1103 \mathrm{P}$ and 41 B grapevine rootstocks. As a result of the research, they said that bacterial inoculation has a positive effect on the vegetative development of the rootstocks and on the chlorophyll concentrations of the leaves and that the A. brasilense Sp 245 and B. subtilis OSU-142 strains used in the research were more efficient than other strains, and that bacteria had significant potential in reducing the need for inorganic fertilizers.

\begin{tabular}{|c|c|c|c|c|c|c|c|c|c|c|c|}
\hline PGPR & $\begin{array}{c}\mathrm{Pb}\left(\mathrm{NO}_{3}\right)_{2} \\
\mathrm{Ppm}\end{array}$ & $\mathbf{P}$ & $\mathbf{K}$ & $\mathrm{Ca}$ & Mg & Mn & $\mathbf{F e}$ & B & $\mathrm{Cu}$ & $\mathbf{Z n}$ & $\mathbf{P b}$ \\
\hline & & \multicolumn{4}{|c|}{$\mathrm{g} / 100 \mathrm{~g}$} & \multicolumn{6}{|c|}{$\mathrm{mg} / \mathrm{kg}$} \\
\hline \multirow[t]{3}{*}{ Inoculated } & 0 & $1,127 \mathrm{ab}^{*}$ & $4,263 \mathrm{ab}$ & $1,972 \mathrm{a}$ & $0,412 \mathrm{ab}$ & $15,00 \mathrm{ab}$ & 23,00 & $69,22 \mathrm{ab}$ & $8,332 \mathrm{ab}$ & $12,24 \mathrm{ab}$ & $0,98 \mathrm{c}$ \\
\hline & 10 & $1,288 \mathrm{a}$ & $5,405 \mathrm{a}$ & $1,367 \mathrm{~b}$ & $0,498 \mathrm{a}$ & $18,00 \mathrm{a}$ & 28,00 & $58,32 \mathrm{bc}$ & $7,861 \mathrm{abc}$ & $12,558 \mathrm{ab}$ & $1,26 \mathrm{bc}$ \\
\hline & 25 & $1,043 \mathrm{ab}$ & $3,546 \mathrm{~b}$ & $1,475 b$ & $0,422 \mathrm{ab}$ & $12,00 \mathrm{~b}$ & 22,00 & $51,42 \mathrm{c}$ & $7,120 \mathrm{bc}$ & $10,050 \mathrm{bc}$ & $1,32 \mathrm{bc}$ \\
\hline \multirow[t]{3}{*}{ Uninoculated } & 0 & $1,250 \mathrm{a}$ & $4,671 \mathrm{ab}$ & $1,578 \mathrm{ab}$ & $0,407 \mathrm{ab}$ & $12,00 \mathrm{~b}$ & 25,00 & $76,62 \mathrm{a}$ & $9,956 \mathrm{a}$ & 14,893 a & $1,21 \mathrm{bc}$ \\
\hline & 10 & $0,892 b$ & $4,038 \mathrm{~b}$ & $1,506 \mathrm{~b}$ & $0,480 \mathrm{ab}$ & $14,00 \mathrm{ab}$ & 24,00 & $67,71 \mathrm{abc}$ & $7,880 \mathrm{abc}$ & $8,859 \mathrm{c}$ & $1,66 \mathrm{~b}$ \\
\hline & 25 & $0,868 \mathrm{~b}$ & $3,588 \mathrm{~b}$ & $1,335 \mathrm{~b}$ & $0,360 \mathrm{~b}$ & $13,00 \mathrm{~b}$ & 21,00 & $53,83 \mathrm{bc}$ & $5,910 \mathrm{c}$ & $10,058 \mathrm{bc}$ & $2,37 \mathrm{a}$ \\
\hline
\end{tabular}

Table 3: Effects of PGPR applications on leaf mineral content in the lead stress.

*: There is a statistical difference between the averages shown with different letters in the same column $(\mathrm{P} \leq 0.05)$. 


\section{Conclusion}

It is extremely difficult to purify the soil from lead and similar elements that are not absolutely necessary for plants but negatively affect growth and development and restrict vegetable production as a pollutant. Environmental approaches that reduce the effectiveness of pollutants in soils and also promote plant growth and development have great importance. PGPRs are important biological preparations which positively affect plant development due to functions such as providing phytohormone and vitamin synthesis, inhibiting ethylene synthesis, increasing stress resistance, facilitating nutrient intake and phosphate solving, as well as preventing the harms of heavy metals. By increasing the use of these environmentally friendly biopreparates, the input of synthetic chemicals used for various purposes in agricultural production will be reduced and the production cost will decrease due to this reason. These applications are also important in sapling production, and the obtained research results cover all plant production. In addition, studies on these bacterial groups, which are increasing in number day by day and their mechanisms of action need to be conducted in detail.

\section{Acknowledgements}

E.S.C contributed to this work in the experimental design and setup, lab processing of samples, data analysis, manuscript writing and discussion. S.D contributed to lab processing of samples, data interpretation, manuscript writing and discussion. The authors read and approved the manuscript. This work was financially supported by the Yozgat Bozok University Department of Scientific Research Projects (6602 b-ZF/17-102).

\section{Conflict of Interest}

The authors declare no conflict of interest.

\section{Bibliography}

1. Ozbolat $\mathrm{G}$ and Tuli A. "Effects of heavy metal toxicity on human health". Archives Medical Review Journal 25 (2016): 502521.

2. Yücel E., et al. "Myriophyllum spicatum (Spiked water-milfoil) as a biomonitor of heavy metal pollution in Porsuk Stream/ Turkey". Biological Diversity and Conservation 3 (2010): 133144.

3. Nedelkoska TV and Doran PM. "Characteristics of heavy metal uptake by plants species with potential for phytoremediation and phytomining". Minerals Engineering 13 (2000): 549-561.

4. Steffens JD. "The Heavy Metal-Binding Peptides of Plants". Annual Review Plant Physiology Molecular Biology 41 (1990): 533-575.
5. Sharma P and Dubey S. "Lead toxicity in plants". Brazilian Journal of Plant Physiology 17 (2005): 35-52.

6. Ghani A., et al. "Effect of lead toxicity on growth, chlorophyll and lead $(\mathrm{Pb})$ content of two varieties of maize (Zea mays L.)". Pakistan Journal of Nutrition 9 (2010): 887-891.

7. Poschenrieder CH., et al. "Influence of cadmium on water relations, stomatal resistance and abscisic acid content in expanding bean leaves". Plant Physiology 90 (1989): 1365-1371.

8. Janmohammadi M., et al. "Impact of pre-sowing seed treatments and fertilizers on growth and yield of chickpea (Cicer arietinum L.) under rainfed conditions". Natura Montenegrina, Podgorica 12 (2013): 217-229.

9. Kuran S., et al. "Effect of lead of Some Morphological and Biochemical Properties in Crisp Lettuce Plants (Lactuca sativa var. crispa)". Iğdır University Journal of the Institute of Science and Technology 5 (2015): 83-88.

10. Munzuroglu O and Geckil H. "Effects of metals on seed germination, root elongation, and coleoptile and hypocotyl growth in Triticum aestivum and Cucumis sativus". Environmental Contamination and Toxicology 43 (2002): 203-213.

11. Lovely DR. "Dissimilatory Metal Reduction". Annual Reviews of Microbiology 47 (1993): 263-290.

12. Reed MLE., et al. "Plant growth-promoting bacteria facilitate the growth of the common reed Phargmites australis in the presence of copper or polycyclic aromatic hydrocarbons". Current Microbiology 51 (2005): 425-429.

13. Farwell AJ., et al. "The use of transgenic canola (Brassica napus) and plant growth-promoting bacteria to enhance plant biomass at a nickel-contaminated field site". Plant and Soil 288 (2006): 309-318.

14. Safronova VI., et al. "Root-associated bacteria containing 1-aminocyclopropane-1-carboxylate deaminase improve growth and nutrient uptake by pea genotypes cultivated in cadmium supplemented soil". Biology and Fertility of Soils 42 (2006): 267-272.

15. Fan S., et al. "Abscisic acid induced electrolyte leakage in woody species with contrasting ecological requirements". Physiologia Plantarum 90 (1994): 414-419.

16. Bates L., et al. "Rapid determination of free proline for waterstress studies”. Plant and Soil 39 (1973): 205-207. 
17. Kiselev KV., et al. "The rol-B gene-induced over production of resveratrol in Vitis amurensis transformed cells". Journal of Biotechnology 128 (2007): 681-692.

18. Singleton VL and Rossi JR. "Colorimetry of total phenolics with phosphomolybdic phosphotungstic acid". American Journal of Enology and Viticulture 16 (1965): 144-158.

19. Zhang Y., et al. "PAR-1 kinase phosphorylates Dlg and regulates its postsynaptic targeting at the Drosophila neuromuscular junction". Neuron 53 (2007): 201-215.

20. Zengin FK and Munzuroğlu Ö. "Effect of lead $\left(\mathrm{Pb}^{+2}\right)$ and copper $\left(\mathrm{Cu}^{+2}\right)$ on the growth of root, shoot and leaf of bean (Phaseolus vulgaris L.) seedlings". Gazi University Journal of Science 17 (2004): 1-10.

21. Yolcu H., et al. "Effects of plant growth-promoting rhizobacteria on some morphologic characteristics, yield and quality contents of hungarian vetch". Turkish Journal of Field Crops 17 (2012): 208-214.

22. Hassan W., et al. "Comparative effectiveness of ACC-deaminase and/or nitrogen-fixing rhizobacteria in promotion of maize (Zea mays L.) growth under lead pollution". Environmental Science and Pollution Research 21 (2014): 10983-10996.

23. Ogar A. "Effect of combined microbes on plant tolerance to $\mathrm{Zn}-\mathrm{Pb}$ contaminations". Environmental Science and Pollution Research International 22 (2015): 19142-19156.

24. Cetin M. "Changes in the Amount of Chlorophyll in Some Plants of Landscape Studies". Kastamonu University Journal of Forestry Faculty 16 (2016): 239-245.

25. Karamooz H., et al. "Tolerance and Accumulation of Heavy Metals by Descurainia sophia L". Journal of Chemical Health Risks 7 (2016): 69-78.

26. Wang Q., et al. "Effect of applying an arsenic-resistant and plant growth-promoting rhizobacterium to enhance soil arsenic phytoremediation by Populus deltoides LH05-17". Journal of Applied Microbiology 111 (2011): 1065-1074.

27. Gratão PL., et al. "Cadmium stress antioxidant responses and root-to-shoot communication in grafted tomato plants". Biometals 28.5 (2015): 803-816.

28. Kolupaev YE., et al. "Constitutive and cold-induced resistance of rye and wheat seedlings to oxidative stress". Russian Journal of Plant Physiology 63 (2016): 326-337.
29. Vardharajula S., et al. "Drought-tolerant plant growth promoting Bacillus spp., effect on growth, osmolytes, and antioxidant status of maize under drought stress". International Journal of Plant Production 6 (2011): 1-14.

30. Tewari RK. "Antioxidant responses to enhanced generation of superoxide anion radical and hydrogen peroxide in the copper-stressed mulberry plants". Planta 223 (2006): 1145-1153.

31. Quan LJ., et al. "Hydrogen peroxide in plants: A versatile molecule of the reactive oxygen species network". Journal of Integrative Plant Biology 50 (2008): 2-18.

32. Rodriguez-Serrano M., et al. "Cellular response of pea plants to cadmium toxicity: Cross talk between reactive oxygen species, nitric oxide, and calcium". Plant Physiology 150 (2009): 229-243.

33. Singh UP., et al. "Plant growth-promoting rhizobacteria-mediated induction of phenolics in pea (Pisum sativum) after infection with Erysiphe pisi". Current Microbiology 44 (2002): 396-400.

34. Pazoki A. "Evaluation of flavonoids and phenols content of wheat under different lead, PGPR and Mycorrhiza levels". Biological Forum - An International Journal 7 (2015): 309-315.

35. Pešaković M., et al. "Phenolic composition and antioxidant capacity of integrated and conventionally grown strawberry (Fragaria $\times$ ananassa Duch.)". Open Access CAAS Agricultural Journal 43(2016): 17-24.

36. Dey SK., et al. "Changes in the antioxidative enzyme activities and lipid peroxidation in wheat seedlings exposed to cadmium and lead stress". Brazilian Journal of Plant Physiology 19.1 (2007): 53-60.

37. Zhou DX., et al. "Effects of waterlogging stress on physiological and biochemical index in Alternant phiiloxeroides Hubei". Agricultural Sciences 48 (2009): 585-587.

38. Verma S and Dubey RS. "Lead toxicity induces lipid peroxidation and alters the activities of antioxidant enzymes in growing rice plants". Plant Science 164 (2003): 645-655.

39. Haneef I., et al. "Impact of bio-fertilizers and different levels of cadmium on the growth, biochemical contents and lipid peroxidation of Plantago ovata Forsk". Saudi Journal of Biological Sciences 21 (2014): 305-310. 
40. Sabir A., et al. "Growth and mineral acquisition response of grapevine rootstocks (Vitis spp.) to inoculation with different strains of plant growth-promoting rhizobacteria (PGPR)". Journal of the Science of Food and Agriculture 15 (2012): 2148-2153.

\section{Assets from publication with us}

- Prompt Acknowledgement after receiving the article

- Thorough Double blinded peer review

- Rapid Publication

- Issue of Publication Certificate

- High visibility of your Published work

Website: https://www.actascientific.com/

Submit Article: https://www.actascientific.com/submission.php

Email us: editor@actascientific.com

Contact us: +919182824667 